\title{
SAAMCO, THE SCOPE OF THE DUTY AND LIABILITY FOR CONSEQUENCES
}

\author{
Nick Hegan*
}

The House of Lords' 1996 decision in South Australia Asset Management Corp v York Montague Ltd limiting liability in certain cases of negligent misstatement has been controversial. More recent pronouncements, both judicial and extra-judicial, suggest something of a change in the way judges are analysing the scope of liability for wrongs. This article examines how the SAAMCO decision fits into this new rubric, and whether its policy basis can be better elucidated under it.

\section{INTRODUCTION}

Where should loss attributable to a negligent misstatement fall? In particular, where the loss is due to both the misstatement and the operation of a foreseeable but independent cause such as a market move, how much of the information recipient's loss should be recoverable from the information provider? This is the issue addressed by the House of Lords in South Australia Asset Management Corp v York Montague Ltd (SAAMCO) ${ }^{1}$ and subsequent cases. Those cases have tended to employ the analytical tool of defining the "scope" of the information provider's duty in order to determine his or her liability: if the loss is within the scope of the duty, it is recoverable. This approach has also found favour with the New Zealand Court of Appeal.

This article is organised around two main themes. The first is that the policy basis for the $S A A M C O$ approach is in need of proper elucidation. The second is that, in couching the SAAMCO approach in the language of the scope of the information provider's duty, its true nature is obscured, with consequent possibilities for confusion.

Part II of this article summarises the reasoning in SAAMCO. Part III analyses this reasoning, and sets out some academic criticisms of it. Part IV considers whether liability for consequences in the above circumstances can be dealt with more convincingly by employing the concept of legal causation than by defining the scope of the duty. Difficulties that have been experienced with the

* Submitted as part of the LLB(Hons) programme at Victoria University of Wellington. Recipient of the 2006 Robert Orr McGechan Prize.

1 South Australia Asset Management Corp v York Montague Ltd [1997] AC 191 (HL(E)) [SAAMCO]. 
SAAMCO decision are then re-examined in light of a causation-based approach, as is a selection of New Zealand appellate cases.

\section{THE DECISION IN SAAMCO}

SAAMCO dealt with three appeals by defendant property valuers against the quantum of damages awarded for the provision of negligent valuations. In each case, the plaintiff lenders had required the valuation before making advances on the security of the property. The cases shared the common features that the property had been negligently overvalued, the borrower had defaulted, and the true property value had slumped. In addition, the trial judge had found in each case that, had the valuation been correct, no loan would have been made. ${ }^{2}$

The lenders' loss could therefore be seen as resulting from a combination of the valuers' negligence, the fall in property values, and the borrowers' default. In essence, the question was whether the lender could recover the whole of its loss from the valuer, or whether some lesser award was due.

\section{A Court of Appeal}

In two of the cases, a unanimous Court of Appeal had awarded the lenders full recovery. ${ }^{3}$ In the third case, judgment awarding the lenders full recovery was given at first instance shortly after the Court of Appeal's decision.

The Court of Appeal's decision proceeded along orthodox lines. The starting point was that the object of damages in contract and in tort was to place the injured party in the position he or she would have been had his or her rights been observed. The valuer owed a duty "to take reasonable care to give a reliable and informed opinion on the open market value of the land in question at the date of valuation." 4 The duty had been breached, the breach had caused the lender to enter into the transaction, and, there being no argument that the loss was too remote, the lender was entitled to recover its full loss.

\section{B House of Lords}

\section{The SAAMCO principle}

The House of Lords, however, differed from the Court of Appeal. Lord Hoffmann, giving the only reasoned judgment, disagreed with the Court of Appeal's starting point. He held that a "correct description of the loss for which the valuer is liable must precede any consideration of the measure

2 Such cases are commonly referred to as "no transaction" cases.

3 Banque Bruxelles Lambert SA v Eagle Star Insurance Co Ltd [1995] 2 All ER 769 (CA) [Banque Bruxelles].

4 Ibid, 840 Sir Thomas Bingham MR for the Court. 
of damages." 5 The scope of the valuer's duty in tort was the same as that under the implied contractual promise of reasonable care and skill. But: ${ }^{6}$

[a] duty of care such as the valuer owes does not ... exist in the abstract. A plaintiff who sues for breach

of a duty imposed by the law (whether in contract or tort or under statute) must do more than prove that

the defendant has failed to comply. He must show that the duty was owed to him and that it was a duty

in respect of the kind of loss which he has suffered.

What, then, was the relevant "kind of loss" in respect of which the valuer owed a duty in this case? Lord Hoffmann reasoned that normally "the law limits liability to those consequences which are attributable to that which made the act wrongful." ${ }^{7}$ He then stated his key principle: "in the case of liability in negligence for providing inaccurate information, liability should be limited to the consequences of the information being inaccurate". ${ }^{8}$

The relevant "kind of loss" was therefore the kind that would not have occurred if the information had been correct. In the circumstances, a duty of care "which imposes upon the informant responsibility for losses which would have occurred even if the information which he gave had been correct is not ... fair and reasonable as between the parties." 9

The "consequences of the information being inaccurate" is a phrase open to misinterpretation. On one view, that the transaction was entered at all was such a consequence. However, it is clear that Lord Hoffmann is referring to a question that may only be answered by reference to a counterfactual or hypothetical world: what would have occurred even if the information had been accurate? As his Lordship said in Nykredit Mortgage Bank Plc v Edward Erdman Group Ltd (No 2): 10

the valuer owes no duty of care to the lender in respect of his entering into the transaction as such and ... it is therefore insufficient, for the purpose of establishing liability on the part of the valuer, to prove that the lender is worse off than he would have been if he had not lent the money at all. What he must show

5 SAAMCO, above n 1, 211 Lord Hoffman.

6 Ibid, 211 Lord Hoffman.

7 Ibid, 213 Lord Hoffman.

8 Ibid, 213 Lord Hoffman. Strictly, what made the act wrongful is not the inaccuracy of the information, but that the statement-maker failed to take reasonable care that the information was accurate. However, the law assumes that, had reasonable care been taken, the information would have been correct: DW McLauchlan "A Damages Dilemma" (1997) 12 JCL 114, 117-118.

9 SAAMCO, ibid, 214 Lord Hoffman.

10 Nykredit Mortgage Bank plc v Edward Erdman Group Ltd (No 2) [1998] 1 All ER 305, 316 Lord Hoffman (HL(E)) [Nykredit]. 
is that he is worse off as a lender than he would have been if the security had been worth what the valuer said.

The SAAMCO principle thus envisages that liability for real-world loss is offset by any loss that would have occurred in the hypothetical world where the information was accurate.

Lord Hoffmann illustrated his principle by reference to an example. A doctor negligently pronounces a mountaineer's knee as fit. The mountaineer subsequently suffers a foreseeable mountaineering injury unconnected with the state of his knee. Had he known the true state of his knee, he would not have undertaken the expedition. On the SAAMCO principle, the doctor is not liable: the "injury has not been caused by the doctor's bad advice because it would have occurred even if the advice had been correct."11 His Lordship then applied the Court of Appeal's reasoning (under which he thought the doctor would be liable), ${ }^{12}$ and found it unsatisfactory: "it would seem paradoxical that the liability of a person who warranted the accuracy of the information should be less than that of a person who gave no such warranty but failed to take reasonable care."13

Lord Hoffmann did, however, introduce an important exception to his principle by creating a dichotomy between "a duty to provide information for the purpose of enabling someone else to decide upon a course of action and a duty to advise someone as to what course of action he should take." 14 In the former case, the SAAMCO principle applies; in the latter, it does not, and liability is for all foreseeable loss that is a consequence of the course of action taken. His Lordship also commented that fraud was another possible exception, but preferred not to express a view as the question did not arise in the instant cases. ${ }^{15}$

\section{Applying the principle: the SAAMCO rule}

As all three cases were "no transaction" cases, the consequence of the valuations being wrong was that the lenders had less security than they thought. ${ }^{16}$ Applying the SAAMCO principle that liability should be limited to the consequences of the information being inaccurate, in the "no transaction" negligent valuer cases Lord Hoffman held that the lenders could not recover more than the amount by which their anticipated security exceeded their actual security, or, in other words, the

11 SAAMCO, above n 1, 213 Lord Hoffman.

12 It is questionable whether the Court of Appeal would have found the doctor liable, as the Court might well have regarded the injury as not caused by the breach: McLauchlan "Damages Dilemma", above n 8, 129131.

13 SAAMCO, above n 1, 213-214 Lord Hoffman.

14 Ibid, 214 Lord Hoffman (emphasis in original).

15 The fraud exception was subsequently confirmed in Smith New Court Securities Ltd v Scrimgeour Vickers (Asset Management) Ltd [1997] AC 254 (HL(E)).

16 SAAMCO, above n 1, 222 Lord Hoffman. 
amount of the initial overvaluation. ${ }^{17}$ This cap on recovery at the level of the overvaluation will be referred to below as the SAAMCO "rule".

\section{ANALYSIS}

\section{A Reconciling the Principle and the Rule}

While the SAAMCO rule is straightforward to apply, it is perhaps not immediately obvious how its cap on recovery at the level of the overvaluation relates to the SAAMCO principle of reducing liability for the real world loss by the amount of loss that would have been suffered in the hypothetical world where the valuation was accurate. To reconcile the principle with the rule, more work is required.

Given the importance of the hypothetical world to the SAAMCO principle, it is necessary to be clear on what the details of that world are. In the valuer cases, the lender's loss results from a combination of circumstances - the negligence of the valuer, the default of the borrower, and the fall in the property market. Lord Hoffmann's hypothetical world differs from the real world only in that the property in question can initially be valued without negligence at the figure represented by the valuer. Other details remain constant between worlds: the property market falls in both, the borrower defaults in both, and the lender's claim on default against the security of the property is the same in both. ${ }^{18}$

Consider, for example, a property with actual value $\$ 10 \mathrm{~m}$ negligently valued at $\$ 15 \mathrm{~m}$. The lender advances $\$ 11 \mathrm{~m}$; the market falls, the borrower defaults and the property is subsequently sold for $\$ 5 \mathrm{~m} .{ }^{19}$ Evidence of the fall in value of similar property correctly valued at $\$ 15 \mathrm{~m}$ shows that, in the hypothetical world, the subsequent sale price would have been $\$ 12 \mathrm{~m}$. Thus the lender has lost $\$ 6 \mathrm{~m}$ (\$11m less \$5m), but in the hypothetical world would have recovered its whole advance and therefore suffered no loss at all.

Applying the SAAMCO principle, the lender can recover its loss $(\$ 6 \mathrm{~m})$ less what its loss would have been in the hypothetical world (nil). The lender thus recovers $\$ 6 \mathrm{~m}$. By contrast, under the $S A A M C O$ rule, the lender recovers the lesser of its loss $(\$ 6 \mathrm{~m})$ and the $\$ 5 \mathrm{~m}$ overvaluation, or in other words $\$ 5 \mathrm{~m}$. On the face of it, the principle and the rule are inconsistent.

17 SAAMCO, above n 1, 222 Lord Hoffman.

18 It has been noted that, in the hypothetical world, the higher-valued property might well have generated greater income for the borrower, and thus that the borrower might have defaulted at a different time, or been less impecunious on default: McLauchlan "Damages Dilemma", above n 8, 115.

19 In this and following examples, it will be assumed that loss is realised by the sale of the property, and that no question of any failure to mitigate arises. There is, of course, no consequent loss of generality as far as the $S A A M C O$ principle is concerned. 
Both the principle and the rule involve a comparison between the actual and hypothetical worlds. However, the rule focuses on the overvaluation, which is a comparison of property values as at the time the valuation was made. In contrast, the principle focuses on a comparison of loss flowing from property values as at the time of sale. This observation is the key to understanding the relationship between the principle and the rule.

Under the principle, the lender's recovery is the actual loss, less the hypothetical world loss. There are two possible scenarios: either the hypothetical world loss is nil, or it is not. In the former case, the lender recovers its actual loss, which is the difference between the amount due and the actual sale price. In the latter case, the lender recovers the actual loss, less the hypothetical world loss, which is just the difference between the hypothetical world sale price and the actual sale price. Since the hypothetical loss is zero precisely when the amount due is less than the hypothetical world sale price, the two scenarios can be combined: in all cases the lender's recovery under the SAAMCO principle is the lesser of the actual loss, and the difference between the hypothetical world sale price and the actual sale price.

This formulation may be compared with the SAAMCO rule that the lender's recovery is the lesser of the actual loss, and the overvaluation. For the rule and the principle to coincide, it follows that the overvaluation must be equal to the difference between the hypothetical world sale price and the actual sale price. However, the overvaluation is just the difference between the initial hypothetical world price and the initial actual world price. Therefore, to get to the rule from the principle, it is necessary to assume that the property's extra value in the hypothetical world is the same at the time of valuation as at the time of sale. In other words, to reconcile the rule and the principle, it is necessary to assume that the hypothetical world property price experiences the same dollar decline as the real world price did. In applying the rule to the SAAMCO facts, Lord Hoffmann implicitly makes this assumption.

This hidden assumption also explains the difficulty with the example above. There, the hypothetical world property price decline was $\$ 3 \mathrm{~m}$, whereas the real world price decline was $\$ 5 \mathrm{~m}$. The declines were not equal, and the principle and the rule gave inconsistent results.

Although Lord Hoffmann implicitly makes the equal dollar decline assumption, his judgment contains no discussion on the point. It may be questioned whether the assumption is justified in principle. Another rule might be just as plausible: for example, one might equally assume that the hypothetical world property price experiences the same percentage decline as the real world price. On that view, the $S A A M C O$ rule is favourable to lenders: because the represented value exceeds the actual value and the dollar price declines are the same, the percentage decline in value in the hypothetical world will always be less than that in the real world. And why should it not be open to a party to adduce evidence as to the actual fall in market value of a comparable property with an initial actual value of the same order as the represented value? If such evidence were available, the SAAMCO principle could be applied in a way truer to its aims. 


\section{B Paradox Lost?}

One strand in Lord Hoffmann's reasoning towards justification of his principle was the purported paradox that "the liability of a person who warranted the accuracy of the information should be less than that of a person who gave no such warranty but failed to take reasonable care."20 It is now accepted that this is not only not a paradox, but an "inevitable concomitant of settled law governing the distinction between liability in tort for misrepresentation and liability in contract for breach of warranty." ${ }^{21}$ As Stapleton observes: ${ }^{22}$

Buying a warranty from one's contracting party is a completely different deal than obtaining an obligation of care. If one accepts that the law of contract damages should not allow the plaintiff to shift the bad bargain on to the defendant, it is not paradoxical that the fate into which the former deal locks its buyer might be worse than that of the person protected by the latter. In terms of the protection of the law of contract damages, a contractual warranty can leave you worse off than an entitlement to due care.

This passage was cited by Lord Steyn in Aneco Reinsurance Underwriting Ltd v Johnson \& Higgins Ltd. ${ }^{23}$ Although his Lordship did not find it necessary to consider the point, it may be speculated that, had he disagreed, he might well have said so. In the event, he contented himself to point out that "the comparison between warranties and obligations to take reasonable care was only one strand of Lord Hoffmann's reasoning". ${ }^{24}$

\section{A Whiff of a Warranty}

Although there is no true paradox, a natural question to ask is whether the SAAMCO principle in fact achieves Lord Hoffmann's desired result: does it ensure that warranty liability is no less than liability under a duty to take reasonable care? More precisely, in a situation where the statementmaker warrants the truth of certain representations, or alternatively has a duty to take reasonable care that those representations are correct, does the SAAMCO principle ensure the liability in the former case is no less than that in the latter?

McLauchlan has argued that the desired result does not necessarily follow. ${ }^{25}$ Slightly altering his figures, suppose the lender purchases a warranty that the property is worth $\$ 15 \mathrm{~m}$ at the time of

20 SAAMCO, above n 1, 213-214 Lord Hoffman.

21 McLauchlan "Damages Dilemma", above n 8, 121-122.

22 Jane Stapleton "Negligent Valuers and Falls in the Property Market" (1997) 113 LQR 1, 5.

23 Aneco Reinsurance Underwriting Ltd (in liquidation) v Johnson \& Higgins Ltd [2002] 1 Lloyd's Rep 157, para 38 (HL(E)) Lord Steyn [Aneco].

24 Ibid.

25 DW McLauchlan "Negligent Valuer Liability: The Paradox Remains?" (1997) 113 LQR 421, 423-424; McLauchlan "Damages Dilemma", above n 8, 127-129. 
valuation. Its actual value is $\$ 5 \mathrm{~m}$, and the lenders advance $\$ 11 \mathrm{~m}$. The borrower defaults and the property is sold for $\$ 2.5 \mathrm{~m}$.

The object of damages for breach of contract is to place the lender in the position it would have been if the contract had been performed. ${ }^{26}$ The warranty is of the value as at the date of valuation only. In assessing damages for breach of warranty, the question is therefore what a property worth $\$ 15 \mathrm{~m}$ at the time of valuation would have been worth at the time of sale. Assuming an equal percentage decline, the property would have been worth $\$ 7.5 \mathrm{~m}$, so that the lender recovers the difference between the actual sale price and what it would have been: $\$ 5 \mathrm{~m}$. By contrast, if instead the valuer had given a valuation of $\$ 15 \mathrm{~m}$ under a duty to take reasonable care, the SAAMCO rule figure for liability would be the lesser of the loss and the overvaluation, or $\$ 8.5 \mathrm{~m}$.

This inconsistency of result does not, however, show that Lord Hoffmann's "paradox" remains. Rather, it results from a particular assumption about what would have happened to property prices in the hypothetical world. As explained above, to reconcile the SAAMCO rule with the SAAMCO principle, it is necessary to make an implicit assumption about the behaviour of property prices in the hypothetical world: they decline dollar for dollar with real world prices. Comparing a SAAMCO rule due care figure with a warranty figure based on equal percentage declines in property values can therefore be argued to be not comparing like with like.

This observation prompts the question of how warranty and due care liability would compare under a consistent property price decline assumption, be it dollar-for-dollar or otherwise. The measure of damages under the warranty is that which puts the lender in the position it would have been in if the warranted facts were true. If those facts were true, the property would have had the represented value as at the time of valuation, and thus have been sold for the hypothetical world sale price, not the actual sale price. Warranty damages are therefore the hypothetical world sale price less the actual sale price. But as already discussed, due care damages under the SAAMCO principle are the lesser of the actual loss, and the hypothetical world sale price less the actual sale price. Due care damages under the SAAMCO principle can therefore be seen as the lesser of warranty damages and the actual loss. They cannot therefore exceed warranty damages, and Lord Hoffmann's "paradox" is indeed eliminated.

\section{Allocation of Risk Between the Parties}

The Court of Appeal's decision in SAAMCO left a nagging objection: in a "no transaction" case, should a negligent valuation leave the valuer as insurer of market decline despite the fact that the valuation was not material to the lender's assessment of that risk? ${ }^{27}$ By deducting, from the lender's

27 It may be argued that, absent the prospect of a market fall, the lender is, in a sense, taking on no real risk at all. 
actual transaction loss, the loss on the transaction that the lender thought it was entering, the $S A A M C O$ principle may be argued to address this objection. As Lord Nicholls observed in Nykredit, the valuer is not liable for all the consequences which flow from the lender entering into the transaction, because "they are the consequences of risks the lender would have taken upon himself if the valuation advice had been sound."28

This line of reasoning has intuitive appeal. The SAAMCO principle allocates loss, and in doing so allocates in a broad way between the parties the risks of the transaction. As noted above, the lender's recovery under the principle is the actual loss, less the hypothetical world loss. However, the hypothetical world loss can be seen as the amount, in the hypothetical world, by which the market fall exceeds the lender's anticipated security buffer. Thus the valuer's liability is the lender's actual loss, less the amount, in the hypothetical world, by which the market fall exceeds the lender's anticipated security buffer. In this way, market falls in excess of the buffer are borne by the lender, but the valuer bears market falls up to the buffer. ${ }^{29}$

While the Court of Appeal's approach may be seen as creating an unjust allocation of risks between the parties, the justice of a result where market fall is allocated to the valuer in relation to a threshold over which he or she had no control may also be pondered. Indeed, the SAAMCO approach has been described somewhat equivocally by Lord Hobhouse as "essentially a legal rule which is applied in a robust way without the need for fine tuning or a detailed investigation of causation," 30 and, less equivocally, criticised as a "cookie cutter." 31 While the SAAMCO principle is an improvement on the Court of Appeal's approach in this regard, clearly scope exists for a more principled approach to the allocation of risk. ${ }^{32}$

\section{SCOPE OF DUTY OR LIABILITY FOR CONSEQUENCES?}

\section{A The Scope of the Duty and the "Kind" of Damage}

Lord Hoffmann couched his principle in the language of scope of duty: the lender must show that "the duty was owed to him and that it was a duty in respect of the kind of loss which he has suffered." 33 As noted above, the "kind" of loss his Lordship was referring to was the kind that

28 Nykredit, above n 10, 309 Lord Nicholls.

29 See also SM Waddams "Liability of Valuers: Kenny \& Good Pty Ltd v MGICA (1992) Ltd" (1997) 5 Torts LJ 218.

30 Platform Home Loans Ltd v Oyston Shipways Ltd [2000] 2 AC 190, 207 (HL(E)) Lord Hobhouse [Platform Home Loans].

31 Alexander Loke "The Valuer's Liability for Negligent Valuation - Toward a More Principled Allocation of the Risk of Market Decline" (1999) 19 Leg S 47, 54-56.

32 See ibid, 63-67.

33 SAAMCO, above n 1, 211 Lord Hoffman. 
would not have occurred if the information had been correct. In making this assertion, he cited Lord Bridge's well-known dictum in the auditors' negligence case of Caparo Industries Plc v Dickman: ${ }^{34}$

It is never sufficient to ask simply whether A owes B a duty of care. It is always necessary to determine the scope of the duty by reference to the kind of damage from which A must take care to save B harmless.

Lord Bridge was here dealing with the argument on behalf of the plaintiff investor that a shareholder selling at an undervalue in reliance on an auditor's negligent report was entitled to recover his loss from the auditor. The plaintiff argued that there could be no distinction between that case and the instant case of purchase at an overvalue by an existing shareholder of additional shares in reliance on a negligent report. ${ }^{35}$

Lord Bridge disposed of this argument on two grounds. Assuming a claim in the "undervalue" case could be sustained, he first noted that purchases and sales in reliance on an auditor's report were different: the loss flowing from sale at an undervalue was not by reason of reliance on the auditor's report, but was "referable to the depreciatory effect of the report on the market value of the shares before ever the decision of the shareholder to sell was taken". ${ }^{36}$ Secondly, he made the key observation that: ${ }^{37}$

the loss in the case of the sale would be ... a loss of part of the value of the shareholder's existing holding, which ... might sensibly lie within the scope of the auditor's duty to protect. A loss, on the other hand, resulting from the purchase of additional shares would result from a wholly independent transaction having no connection with the existing shareholding. ... I believe it is this last distinction which is of critical importance ...

Lord Bridge then generalised from this statement to the dictum cited by Lord Hoffmann. It would thus appear that the "kind" of damage that Lord Bridge was referring to was the kind that arose from an independent transaction, not the kind that would not have arisen had the auditor's report been correct.

In support of his dictum, Lord Bridge referred ${ }^{38}$ to Brennan J's judgment in The Council of the Shire of Sutherland $v$ Heyman. ${ }^{39}$ The case concerned the council's liability for a negligent building inspection. In the passage referred to by his Lordship, Brennan J held: ${ }^{40}$

34

35

Caparo Industries Plc v Dickman [1990] 2 AC 605, 627 (HL(E)) Lord Bridge.

Ibid, 626 Lord Bridge.

Ibid, 627 Lord Bridge.

Ibid.

Caparo Industries Plc v Dickman, above n 34, 627.

The Council of the Shire of Sutherland v Heyman (1985) 60 ALR 1 (HCA). 
It is impermissible to postulate a duty of care to avoid one kind of damage - say, personal injury - and, finding the defendant guilty of failing to discharge that duty, to hold him liable for the damage actually suffered that is of another and independent kind - say, economic loss. ... The question is always whether the defendant was under a duty to avoid or prevent that damage, but the actual nature of the damage suffered is relevant to the existence and extent of any duty to avoid or prevent it.

Here Brennan J appears to be distinguishing the "kind" of damage according to the orthodox categories of personal injury, economic loss and (presumably) damage to property.

The "kind" of damage is a slightly slippery term. It is not immediately clear in what way the reasoning referred to by Lord Hoffmann and Lord Bridge supports their arguments, except perhaps to say that it exemplifies Lord Denning's observation that "[t]he truth is that all these three - duty, remoteness and causation - are all devices by which the courts limit the range of liability for negligence ... [U]ltimately it is a question of policy for the judges to decide." 41

It may also be noted that Lord Hoffmann's limitation on the scope of the duty is crucially different to that discussed by Lord Bridge and Brennan J. Lord Hoffmann's approach limits the duty not according to the purpose for which the plaintiff uses the negligently provided information, or the orthodox category of damage, but according to a counterfactual enquiry: what portion of the loss would not have occurred if the information had been correct? As Lord Hobhouse observed in Platform Home Loans, the "development of this reasoning ... was that Lord Hoffmann, instead of applying it to kinds or categories of damage, applied it to the quantification of damage." 42 There is a difference between using the duty concept to determine whether there is liability for a particular head of loss, and the extent of that liability. ${ }^{43}$ Lord Hoffmann's novel usage begs the question of the consequences of such an addition to the "kind" of damage distinguished by the law.

\section{B Scope of the Duty: Criticisms of the Approach}

The difficulty with this line of reasoning has not gone unnoticed. In Aneco, Lord Millett, referring to an article by Stapleton, ${ }^{44}$ observed: ${ }^{45}$

40 Ibid, 48 Brennan J.

41 Lamb v Camden London Borough Council [1981] QB 625, 636 (CA) Lord Denning MR.

42 Platform Home Loans, above n 30, 209 Lord Hobhouse (emphasis in original).

43 Loke, above n 31, 49.

44 Jane Stapleton "Legal Cause: Cause-in-Fact and the Scope of Liability for Consequences" (2001) 54 Vand LR 942.

45 Aneco, above n 23, para 57 Lord Millett. 
Despite the way in which Lord Bridge formulated the issue, I think that it is conceptually better to say that the defendant's liability for the consequences of his actions is limited by reference to the scope of the duty than to say that the duty itself is owed only with respect to a particular kind of loss.

Stapleton herself argues that the law of negligence is most rationally approached by maintaining "a distinction between the incidence of an obligation and the scope of liability for consequences of tortious conduct." 46 The essential distinction is that the first element is directed towards the behaviour of the tortfeasor, while the second addresses the consequences of the behaviour for which the tortfeasor is to be held liable. Stapleton argues that the two elements are often conflated because foreseeability is a prerequisite for incidence of obligation, as well as relevant to the extent of liability for consequences. ${ }^{47}$

This kind of conflation is particularly apparent in "scope of the duty" arguments. The "scope of the duty" clearly relates to the incidence of obligation: if one is outside the scope of one's duty, no obligation arises. Yet, as with the SAAMCO principle, the rationale for the restriction of the duty is often that there are consequences for which it is argued that the tortfeasor cannot fairly be held liable. As Stapleton observes, the "idea that the obligation is to act reasonably only in relation to one of the array of foreseeable risks is ... an incoherent one in theory and certainly extraordinarily awkward as a guide to conduct." 48

\section{Liability for Consequences}

Some of Lord Hoffmann's language in SAAMCO employs the language of causation, not duty. For example, in his Lordship's mountaineer example, ${ }^{49}$ he says that the injury "has not been caused by the doctor's bad advice because it would have occurred even if the advice had been correct." 50 He also finds that the result of application of the Court of Appeal's reasoning to the mountaineer case "offends common sense" because "it makes the doctor responsible for consequences which ... do not appear to have a sufficient causal connection with the subject matter of the duty." 51 Further, Lord Hoffmann found implicit support for his principle in Banque Keyser Ullmann SA v Skandia

\footnotetext{
46 Stapleton "Legal Cause", above n 44, 988.

$47 \quad$ Ibid, 989.

48 Ibid, 996.

49 See Part II.

50 SAAMCO, above n 1, 213 Lord Hoffman.

51 Ibid, 214 Lord Hoffman.
} 
(UK) Insurance Co Ltd, ${ }^{52}$ even though "Lord Templeman ... dealt with the matter in terms of causation." 53

These instances aside, Lord Hoffmann's reasoning in SAAMCO was squarely within the scope of the duty. As his Lordship observed in Nykredit, "it is important to emphasise that [the SAAMCO principle] is a consequence of the limited way in which the House defined the valuer's duty of care and has nothing to do with questions of causation". 54

However, the approach of Lord Hoffmann's Blackstone Lecture at Pembroke College, Oxford in May 2005, suggests a fundamental change in position. ${ }^{55}$ The cornerstone of his Lordship's speech is the thesis, attributed to Hart and Honoré, ${ }^{56}$ that the concept of causation is used by the law as a tool for apportioning responsibility. The law must therefore not only define the conduct giving rise to liability, but must also define the occurrences for which the tortfeasor is treated as liable. ${ }^{57}$

His Lordship defines as the "standard criteria" of limits of liability for negligence the "general rules of common sense" that the defendant caused the harm if "but for his act, it would not have happened and if there has been no other intentional human act or subsequent unusual natural occurrence without which the harm would not have happened." 58 Crucially, and perhaps more controversially, he observes that what constitutes a sufficient causal connection is a question of law, and that the standard criteria may be departed from in an appropriate case. ${ }^{59}$ In particular, Lord Hoffmann regards liability for negligent misstatement as being an appropriate occasion for departure from the standard criteria. He restates the $S A A M C O$ principle as based on a legal restriction in the consequences for which the negligent valuer is liable. ${ }^{60}$ Noting that in SAAMCO he approached this issue via the scope of the duty of care, he adds: ${ }^{61}$

Other judges have also spoken about the scope of the duty. Professor Jane Stapleton has pointed out that the language is inappropriate. The scope of the duty of care is to take reasonable care to get the valuation right. It has nothing to do with the extent of the consequences for which the valuer is liable. When one

52 Banque Keyser Ullmann SA v Skandia (UK) Insurance Co Ltd [1991] 2 AC 249 (HL(E)).

53 SAAMCO, above n 1, 215 Lord Hoffman.

54 Nykredit, above n 10, 316.

55 Rt Hon Lord Leonard Hoffmann "Causation" (2005) 121 LQR 592.

56 In HLA Hart and AM Honoré Causation and the Law (Oxford University Press, Oxford, 1959).

57 Lord Hoffmann, above n 55, 595.

58 Ibid, 594.

59 Ibid, 597.

60 Ibid, 595-596.

61 Ibid, 596. 
considers what causal relationship is required, one is really speaking about extent of the liability and not about the scope of the duty. Professor Stapleton is right. I shall try to mend my language in future.

Lord Hoffmann thus accepts Stapleton's distinction between incidence of obligation and extent of liability for consequences. He accepts that the SAAMCO principle is inappropriately dealt with in the scope of the duty, but instead recasts it, via the medium of legal causation, as a restriction on extent of liability for consequences.

\section{Connecting the Content of the Duty and Liability for Consequences}

It may be argued that the standard criteria referred to by Lord Hoffmann are only a guideline in any event. Third-party liability cases are a textbook example. For example, in Attorney General of the British Virgin Islands $v$ Hartwell, ${ }^{62}$ the police were found to be liable for negligently allowing a junior officer access to a revolver. The officer subsequently vacated his post, travelled 27 miles by boat and road to a bar where his partner worked, and fired the gun, in the event missing his target and injuring the plaintiff. Thus in that case the "standard criteria" were departed from, in that an intentional human act did not preclude liability being sheeted home to the police. ${ }^{63}$

In accepting that the scope of duty is an inappropriate way in which to deal with extent of liability for consequences, Lord Hoffmann observed that "[t]here is a close link between the nature of the duty and the extent of liability for breach of that duty." ${ }^{64}$ In other words, the wider or stronger the duty, the wider the extent of liability imposed by the law. A similar theme had been espoused by Lord Nicholls in Kuwait Airways Corporation v Iraqi Airways Co, ${ }^{65}$ where his Lordship held that damages in tort depend on the "value judgment" 66 of "the extent of the loss for which the defendant ought to be held liable"67 given "the reasons why the law has recognised the cause of action in question." 68

This connection can be seen in various guises throughout the law. For example, in Environment Agency v Empress Car Co (Abertillery) Ltd, ${ }^{69}$ Lord Hoffmann argued that the nature of the offence, one of strict liability for environmental damage, led to the standard criteria for extent of liability for

\footnotetext{
62 Attorney General of the British Virgin Islands v Hartwell [2004] 1 WLR 1273 (PC) [Hartwell].

63 See also Reeves $v$ Commissioner of Police of the Metropolis [2000] 1 AC 360 (HL(E)), where the suicide of an arrestee did not relieve the defendants of liability for their failure to prevent him doing so.

64 Lord Hoffmann, above n 55, 596.

65 Kuwait Airways Corporation v Iraqi Airways Co (Nos 4 and 5) [2002] 2 AC 883 (HL(E)).

66 Ibid, 1091 Lord Nicholls.

67 Ibid, 1090 Lord Nicholls.

68 Ibid, 1091 Lord Nicholls.

69 Environment Agency v Empress Car Co (Abertillery) Ltd [1999] 2 AC 22 (HL(E)).
} 
consequences being enlarged, so that the owner of a tank of oil was liable for pollution resulting from the act of a vandal in opening the tank's valve. The decision in Hartwell can also be seen through its lens: the Privy Council noted that "where an article as dangerous as a loaded gun is handed over ... the standard of care required is high," 70 and held that the junior officer's intentional act did not relieve the police of their liability. Similarly, the fraud exception to the SAAMCO principle can be seen in its light: the more serious nature of the wrong is linked to more extensive liability for consequences.

While the connection between nature of the duty and extent of liability for consequences can be discerned as a theme in these cases, it does not ex ante provide much guidance as to how the nature of a particular duty is to flow through to liability for consequences. In particular, the observation offers no reason of principle as to why the particular limitation on liability contained in the $S A A M C O$ principle should follow from the nature of the valuer's duty.

\section{Policy Revisited}

Stapleton has argued that, in negligence cases, a clear divide between the nature of the duty and extent of liability for consequences permits the elucidation of a small number of legal rules determining that extent. ${ }^{71}$ In summary, these rules are as follows. First, the loss must fall within the Wagon Mound perimeter of foreseeability. ${ }^{72}$ Secondly, there is no liability for coincidences: where an outcome results from a breach of duty, but the outcome is of a type "the incidence of which is not generally increased by the occurrence of the type of breach in issue," the law generally holds losses associated with the outcome to be outside the extent of the tortfeasor's liability for consequences. ${ }^{73}$ Thirdly, in cases of negligent failure to warn, there is no liability if the outcome is not the one about which the warning should have been given (as in the case of Lord Hoffmann's mountaineer). ${ }^{74}$

The second and third of these rules can perhaps be generalised in the case of negligent misstatement where part of the foreseeable loss is due to the operation of an independent risk. If the advice recipient has fairly and reasonably relied on the advice to assess the potential effect of the independent risk, a fair allocation of risk between the parties holds the advice-giver liable for the whole loss. But if not, the loss allocated to the advice-giver should be reduced to the extent that the

70 Hartwell, above n 62, 1282 Lord Nicholls for the Court.

71 Jane Stapleton "Occam's Razor Reveals an Orthodox Basis for Chester v Afshar" (2006) 122 LQR 426, 436.

72 Overseas Tankship (UK) Ltd v Morts Dock \& Engineering Co Ltd (The Wagon Mound) (No 1) [1961] AC 388 (PC).

73 Stapleton "Occam's Razor", above n 71, 439. This rule is argued to reflect a "normative concern with the deterrence of comparable breaches in the future": ibid, 438. Since more extensive liability would presumably be even more effective to deter breaches, Stapleton must be taken to be referring to legitimate deterrence.

74 Ibid, 446. 
operation of the independent risk has turned to harm. ${ }^{75}$ The SAAMCO principle attempts to make this allocation in a simple (and perhaps simplistic) way, but surely provides greater justice than an approach based on the "standard criteria."

\section{A Distinction without a Difference?}

A change in approach from scope of duty to legal causation may be seen as the same wolf in a different sheep's clothing; merely a different label for the same judicial policy-making. However, as Kirby J has observed, "[l]abels are commonly used by lawyers. They help steer the mind through the task in hand." 76 It is apposite to ask whether any of the difficulties that have been experienced with the SAAMCO principle are ameliorated by a characterisation of it as legal causation rather than as a restriction on the scope of the duty.

The two principal such difficulties that have been experienced with the SAAMCO principle are in its intersection with the law of contributory negligence, and its creation of the dichotomy between the extent of liability for providing information and undertaking to advise.

\section{E Contributory Negligence}

Platform Home Loans ${ }^{77}$ showed that the SAAMCO scope-of-duty restriction leads to difficulties in cases of contributory negligence. In round figures, a lender lent $£ 1.05 \mathrm{~m}$ against a negligent valuation of $£ 1.5 \mathrm{~m}$ when the actual value was $£ 1 \mathrm{~m}$. The property was subsequently sold for $£ 0.4 \mathrm{~m}$. The lender had a policy of lending against 70 per cent of valuation, but the borrower would not have taken the loan had only $£ 0.7 \mathrm{~m}$ been offered, making it a "no transaction" case.

The trial judge made a finding of 20 per cent contributory negligence on the part of the lender. Having found the lender's financial loss to be $£ 611,748$, he awarded damages of 80 per cent of this, or $£ 489,398$, less than the $£ 500,000$ overvaluation. The Court of Appeal, however, applied different logic: absent contributory negligence, only $£ 500,000$ was recoverable; therefore with a 20 per cent contribution, $£ 400,000$ would be awarded.

The lender appealed to the House of Lords. In short, the issue was: where contributory negligence of $\mathrm{X}$ per cent has been found, is the correct measure of damages under the SAAMCO principle $\mathrm{X}$ per cent of the lesser of the overvaluation and the loss, or the lesser of the overvaluation and 100-X per cent of the loss? Clearly the question is of some significance where (and only where)

75 Seen in this way, the SAAMCO principle does not cast "an unsettling light" on the outcome of cases such as Hedley Byrne \& Co Ltd v Heller \& Partners Ltd [1964] AC 465 (HL(E)) as Stapleton claims in "Occam's Razor", above n 71, 436.

76 Perre v Apand Pty Ltd (1999) 198 CLR 180, 283 Kirby J.

77 Platform Home Loans Ltd v Oyston Shipways Ltd, above n 30. 
the overvaluation is less than the loss. The House of Lords decided on the latter formulation (Lord Cooke dissenting). The decision has been subject to both academic criticism ${ }^{78}$ and approval. ${ }^{79}$

Lord Hobhouse and Lord Millett gave the only reasoned speeches for the majority. Lord Hobhouse argued that, if the overvaluation exceeded the loss, clearly the appropriate award was $\mathrm{X}$ per cent of the loss. If the overvaluation was less than the loss, it would not be "just and equitable to make any further reduction. The resultant figure is within the scope of the duty of care which the judge has found that the defendants have breached." 80

Lord Millett noted that the calculation of the lender's loss was "an exercise in causation" but that the calculation of the overvaluation "has nothing to do with questions of causation ... It is designed to ascertain the maximum amount of loss capable of falling within the valuer's duty of care."81 Since the lender's negligence had not contributed to the overvaluation, the correct approach was to award " 80 per cent of the overall loss for which the respondents have been found to be responsible and which, being less than the amount of the overvaluation, fell wholly within the scope of their duty of care." 82

In summary, both Lord Hobhouse and Lord Millett took the approach that, since X per cent of the loss was less than the overvaluation, it was within the scope of the duty of care, and the correct award was therefore $\mathrm{X}$ per cent of the loss. The difficulty with this reasoning is that the relevant contributory negligence legislation operates on the damages recoverable, not the scope of the duty: ${ }^{83}$

Where any person suffers damage as the result partly of his own fault and partly of the fault of any other person or persons, a claim in respect of that damage shall not be defeated by reason of the fault of the person suffering the damage, but the damages recoverable in respect thereof shall be reduced to such

78 DW McLauchlan "Contributory Negligence and the SAAMCO Principle" (1999) LMCLQ 355; Jane Stapleton "Risk-Taking by Commercial Lenders" (1999) 115 LQR 527, 527.

79 Edwin Peel "SAAMCO Revisited" in Andrew Burrows (ed) Commercial Remedies: Current Issues and Problems (Oxford University Press, Oxford, 2003) 55, 63-65.

80 Platform Home Loans, above n 30, 211 Lord Hobhouse. Interestingly, Lord Hobhouse garnered support for his view by noting that, in $S A A M C O$, the reduction for contributory negligence was applied to the lender's loss, not the amount of the overvaluation: the trial judge had found a loss of $£ 9,753,927.99$ as against an overvaluation of $£ 10 \mathrm{~m}$, and the House of Lords applied the reduction to the loss. With respect, it is difficult to see how this observation supports his conclusion, as there is no difference between the two formulations where the loss is less than the overvaluation. In fact, Lord Hobhouse himself noted that, in Platform Home Loans, if the overvaluation had been $£ 615,000$, the SAAMCO principle would have been "irrelevant".

81 Ibid, 213 Lord Millett.

82 Ibid, 215 Lord Millett.

83 Law Reform (Contributory Negligence) Act 1945 (UK) s 1(1). 
extent as the court thinks just and equitable having regard to the claimant's share in the responsibility for the damage.

Logically, as Lord Cooke pointed out, "[o]n the recent authorities the balance of the loss, $£ 111,748$ was not suffered, even in part, as a result of the valuer's fault, because of the limited way in which this House has defined the valuer's duty of care." 84 On a "scope of the duty" approach, the alternative formulation is therefore correct: the reduction should operate on the damages that would have been recoverable absent contributory fault.

On one view, the difficulty here stems from the vagueness of the trial judge's finding of 20 per cent contribution: "contribution to what? 20 per cent of what?" 85 However, an argument based on legal causation suggests a third possible result. The SAAMCO principle compares the position the lender is in with its position in the hypothetical world where the valuation was correct. The valuer's liability for consequences is limited to the difference between the two. If the effect of the lender's negligent behaviour can be ascertained in the hypothetical world, one could argue that any reduction for the lender's negligence is subsumed into the SAAMCO principle. In such a case, the further "just and equitable" reduction required under the Law Reform (Contributory Negligence) Act could be argued to be nil.

For example, on the Platform Home Loans facts, the lender was found negligent in making the loan without having obtained from the borrower information required by its own form, and in advancing as much as 70 per cent of valuation. ${ }^{86}$ In the hypothetical world where the valuation was correct, the lender would therefore have lent the same amount, and presumably still have not obtained the required information. Making the SAAMCO assumption of equal declines in real and hypothetical world property prices, the only difference would have been that the property would have sold for $£ 500,000$ more, for a resultant loss to the lender of $£ 111,748$. The SAAMCO damages awarded on this view would therefore have been $£ 500,000$.

The absurd conclusion of this argument - that the lender's contributory negligence has no effect on the damages payable by the valuer - shows that, in the writer's opinion, the SAAMCO principle is not easily integrated with the law of contribution. The principle effectively holds all else constant while toggling between the real world and a world where the misrepresentation was true. Such an approach is not easily reconcilable with multiple tortfeasors and the law of contribution.

84 Platform Home Loans, above n 30, 199 Lord Cooke.

85 Stapleton, above n 78, 527.

86 Platform Home Loans, above n 30, 212 Lord Millett. 


\section{F The Binary Nature of Liability}

Another problematic feature of the SAAMCO principle is Lord Hoffmann's distinction between a duty to provide information and a duty to advise as to course of action. The side of the line on which a case falls may thus result in significantly different liability for the negligent statement-maker.

This distinction was to the fore in Aneco Reinsurance Underwriting Ltd v Johnson \& Higgins Ltd. ${ }^{87}$ A number of Lloyd's syndicates wished to reinsure part of their marine risk on an excess-ofloss basis. The defendant broker approached the plaintiff reinsurer, Aneco, on their behalf. Aneco expressed interest, provided that it could purchase certain excess-of-loss cover on its own marine account. The broker, now acting for Aneco, obtained the required cover, but in doing so misrepresented the nature of the risk Aneco was assuming from the Lloyd's syndicates. Aneco's insurers avoided their policies on this basis. While the avoided policies would have paid Aneco around US\$11m, its loss on the Lloyd's reinsurance amounted to around US\$35m.

The Court of Appeal, reversing a factual finding below, found that reinsurance on Aneco's terms was not available in the market at all, making it a "no transaction" case. The case thus turned on the factual question of which side of the line the content of the broker's duty fell. Had the broker undertaken to advise as to a course of action (in which case its liability would be the US $\$ 35 \mathrm{~m}$ loss that, but for the misrepresentation, would not have been incurred)? Or had it merely undertaken to provide information as to whether the required cover was available (in which case this liability would be reduced by the US $\$ 24 \mathrm{~m}$ loss that would have occurred even if the information had been true)? The House of Lords (Lord Millett dissenting) decided the former.

Lord Steyn commented that the "brokers were fortunate in obtaining leave to appeal to the House on what turned out to be issues of fact." 88 His Lordship's choice of language is interesting: why had it "turned out" to be an issue of fact, when it was quite clearly one from the start? Part of the confusion can be argued to stem from the "scope of the duty" formulation of the SAAMCO principle. Such a formulation risks confusing the content of the duty - what should the statementmaker have done? - with the extent of liability for consequences - for what should the negligent statement-maker be liable?

Lord Lloyd's judgment illustrates this risk. His Lordship referred to "the ordinary rule, whereby brokers ... are liable in contract for the foreseeable consequences of their negligence ... provided such consequences can fairly be held to fall within the scope of the defendant's duty of care." ${ }^{89}$ His Lordship then described SAAMCO as being "an example of a special class of case - typically that of a valuer, but not confined to valuers - where a scope of the defendant's duty is confined to the

87 Aneco Reinsurance Underwriting Ltd v Johnson \& Higgins Ltd, above n 23.

88 Ibid, para 43 Lord Steyn.

89 Ibid, para 13 Lord Lloyd. 
giving of specific information."90 The incautious reader might well have difficulty separating the two usages made here of the duty concept.

A legal causation approach avoids these difficulties by making a clear division between the incidence of the obligation, and the extent of liability for consequences. It also makes it explicit that the question of whether the SAAMCO principle is or is not to apply is a question of law. It does not, however, assist with resolving the question of what that rule of law is. In Aneco, even the House of Lords disagreed on how this question was to be answered, with Lord Steyn applying Lord Hoffmann's categorisation, ${ }^{91}$ but Lord Millet stating: ${ }^{92}$

Lord Hoffmann was not distinguishing between a duty to provide information and a duty to give advice.

That is a distinction without a difference, for the terms are interchangeable. He was distinguishing

between a duty to provide particular information or advice on request and a duty to advise generally

when it is left to the adviser to decide what matters he should consider.

Lord Millett's observation carries some force. Compare, for example, A's duty to advise B as to whether to take course of action $\mathrm{X}$ or $\mathrm{Y}$, and A's duty to provide information to B on the basis of which B has told A he will decide to do either X or Y. It does not seem sensible to distinguish the consequences for breach of duty in this case. Yet Lord Hoffmann's distinction, if applied formalistically, creates exactly this result.

In the writer's opinion, if the SAAMCO principle is to be accepted, the question of whether it is to apply in a given case should be answered by reference to allocation of risk, rather than by a formalistic information/advice distinction. Applying the approach outlined above, the question to ask is whether the advice recipient fairly and reasonably relied on the advice to assess the independent risk. In the valuer case, the valuation was not relevant to the lender's assessment of the risk of market decline. In Aneco, however, the broker knew that advice as to availability of reinsurance was important to Aneco's assessment of the risk of claims from the Lloyd's syndicate. ${ }^{93}$ The House's decision accords with an allocation of risk rationale.

\section{E The New Zealand Experience}

Although claims against negligent valuers have been few and far between in the recent years of increasing property prices, the SAAMCO principle has fallen to be considered in other kinds of cases

\footnotetext{
90 Ibid, para 13 Lord Lloyd.

91 Ibid, para 37 Lord Steyn.

92 Ibid, para 62 Lord Millett.

93 Ibid, para 40 Lord Steyn.
} 
in New Zealand. Despite the principle's rejection in the High Court of Australia, ${ }^{94}$ it has apparently been accepted at appellate level in New Zealand.

In Bank of New Zealand $v$ New Zealand Guardian Trust Co Ltd, ${ }^{95}$ a debenture trustee had negligently failed to advise lenders of unsecured advances by the borrower to its subsidiaries in breach of a term of the trust deed. The borrower failed, and one of the lenders argued that, had it known of the breach, it would have withdrawn from the facility, or at least had a chance to do so. However, the lender did not establish that the breaches themselves had magnified its loss.

Gault J delivered the judgment of four of a five-member Court. In finding the trustee not liable, his Honour, citing SAAMCO, stated that: ${ }^{96}$

The scope of a duty to inform, or inform correctly, has not commonly been found to extend to protect against losses arising from some independent cause where breach of the duty merely creates or preserves the circumstances in which that loss can be incurred.

This is an orthodox application of the SAAMCO principle, although, with respect, where his Honour refers to the scope of the duty, he is clearly speaking of the extent of liability for consequences, not the content of the duty.

In Benton v Miller \& Poulgrain (a firm), ${ }^{97}$ solicitors conducting property transactions for $\mathrm{Mr}$ and Mrs Benton negligently failed to advise as to potential consequences under relationship property legislation should they separate. Separation eventuated, and Mr Benton claimed that, because of the negligent advice, he had lost the chance to contract out of the legislation, thereby suffering loss.

Despite the discussion in Guardian Trust, Glazebrook and William Young JJ stated that $S A A M C O$ was "addressed to the liability of valuers for damages associated with negligent valuations in a context of falling property values. This is well removed from the issues in this case." 98 They did not discuss the principle further, but appear to have considered that, had it applied, it would have precluded the Court from taking into account the possibility that Mrs Benton might not have agreed to contract out. ${ }^{99}$ With respect, it is difficult to see how the SAAMCO principle is necessarily

94 Kenny \& Good Pty Ltd v MGICA (1992) Ltd (1999) 199 CLR 413; for a concise summary, see DW McLauchlan and CEF Rickett "SAAMCO in the High Court of Australia" (2000) 116 LQR 1.

95 Bank of New Zealand v New Zealand Guardian Trust Co Ltd [1999] 1 NZLR 664 (CA, Full Court) [Guardian Trust].

96 Ibid, 683 Gault J.

97 Benton v Miller \& Poulgrain (a firm) [2005] 1 NZLR 66 (CA).

98 Ibid, para 59 Glazebrook and William Young J.

99 Ibid. 
inconsistent with damages for loss of a chance: in fact, in Guardian Trust, the contrary seems to have been accepted. ${ }^{100}$

Hammond J, however, noted that the application of the SAAMCO principle turned on the content of the duty, and therefore in this case the scope of the relevant retainer. ${ }^{101}$ Characterising this as an "advice" not an "information" case, he held that the principle was not applicable. ${ }^{102}$ With respect, this was correct. However, the majority's reasoning concerning the SAAMCO principle is somewhat troubling.

In Scott $v$ Wilson, ${ }^{103}$ the plaintiff Scott retained the defendant accountants to advise on tax compliance, tax minimisation, and asset protection. Scott, who had a background in foreign exchange, held certain funds in US dollars, believing that the NZ dollar was to depreciate against the US dollar. The defendants negligently failed to advise him that exchange gains on the offshore funds were taxable. The NZ dollar did indeed depreciate, and Scott claimed that, had he known of the true tax position, he would have increased the size of his US fund so as to obtain the same effective exposure to currency movements.

William Young J, giving the judgment of the Court, found that Scott had not discharged the burden of proof in respect of what he would have done had he known the true tax position. ${ }^{104} \mathrm{He}$ also could not succeed for a more fundamental reason: ${ }^{105}$

Cases of this nature require an analysis of whether the consequences in respect of which damages are sought were within the risk intended to be addressed by the services which were provided and, in that sense, the scope of the duty ... Applying this approach, we think that the consequences in respect of which damages are sought were not within the risks which the tax compliance services ... were intended to address.

While it is true that the content of the duty did not include investment advice, it does not follow that investment losses (or, here, gains prevented) consequent on negligent tax advice are not recoverable. Referring back to the allocation of risk argument above, a sophisticated investor such as Scott could be said to be fairly and reasonably relying on the tax advice to assess the effective risks of his investments. In principle, it is difficult to see why the Court found against him on this point.

100 Guardian Trust, above n 95, 685-686 Gault J.

101 Benton v Miller \& Poulgrain (a firm), above n 97, para 89 Hammond J.

102 Ibid, para 99 Hammond J.

103 Scott v Wilson (12 November 2004) CA 15/04.

104 Ibid, para 62-66 William Young J for the Court.

105 Ibid, para 77 William Young J for the Court. 


\section{CONCLUSION}

A legal causation formulation of the $S A A M C O$ principle clarifies the way in which it is to be applied. In particular, the difficulty of reconciling the principle with the law of contribution is exposed, and the risk of confusion between incidence of obligation and liability for consequences present with a "scope of the duty" approach avoided.

A causation-based approach cannot, however, justify the principle itself. Perhaps the best rationale for the principle follows from the observation that liability for consequences of negligent misstatement should in some way be tied back to a fair allocation of risks between the parties. In particular, where the operation of an independent risk has magnified loss, but the advice recipient did not fairly and reasonably rely on the advice to assess that risk, some allocation to the advice recipient of loss that would have occurred even if the advice was correct seems justified. Such a rationale can also be argued to be useful in a principled approach to deciding whether such an allocation of loss should take place at all in a given case: Lord Hoffmann's advice/information distinction lends itself only too easily to formalistic reasoning.

The existence of a rationale for the principle does not, however, mean it is beyond criticism. In particular, the way in which the SAAMCO principle allocates loss between the statement-maker and recipient is open to question, as illustrated in above in the case of the negligent valuer. In addition, the principle, toggling as it does between the real world and a world where the information given by one negligent statement-maker was correct, deals poorly with the situation of multiple tortfeasors. While the rationale is sound, the principle is in need of reformulation. 
(2007) 38 VUWLR 